\title{
UNILATERAL SEGMENTAL APLASIA OF UTERINE HORN ASSOCIATED WITH PYOMETRA AND VULVAR HYPOPLASIA IN A BITCH
}

\author{
A. ANTONOV \\ Department of Obstetrics, Reproduction and Reproductive Disorders, \\ Faculty of Veterinary Medicine, Stara Zagora, Bulgaria
}

\begin{abstract}
Summary
Antonov, A., 2020. Unilateral segmental aplasia of uterine horn associated with pyometra and vulvar hypoplasia in a bitch. Bulg. J. Vet. Med., 23, No 2, 262-267.

The aim of this report was to describe a clinical case of unilateral segmental aplasia of the uterine horn and vulvar hypoplasia associated with pyometra as a complication in a bitch. The patient was presented with abdominal pain, excessive vulvar licking, anorexia and lethargy. The vulva was found hypoplastic, flushed and without any discharge. Ultrasonography revealed an enlarged tip of the left uterine horn filled with fluid. Blood laboratory analysis showed a marked leukocytosis, so diagnosis of pyometra was made. Laparotomy and ovariohysterectomy were performed. During the operation unilateral segmental aplasia of the right uterine horn was observed. This is a very rare case of segmental aplasia of the uterus associated with hypoplasia of the vulva and with clinical signs of systemic disease in the bitch.
\end{abstract}

Key words: bitch, pyometra, segmental aplasia, uterus, vulvar hypoplasia

Congenital abnormalities of the uterus arise from defects in Müllerian (paramesonephric) ducts development during embryogenesis (Kennedy \& Miller, 1993) with prevalence from 0.02 to $0.05 \%$ in the canine population (Roberts, 1971; McIntyre et al., 2010). Segmental aplasia of the uterine horns is accounted for $20 \%$ of the congenital anomalies of the uterus in the bitch, most frequently as unilateral condition (McIntyre et al., 2010), which may develop at any point of the uterine horns (McEntee, 1990; Romagnolli \& Schlafer,
2006; McIntyre et al., 2010) and rarely at uterine body (Oh et al., 2005; Almeida et al., 2010).

There are several reports of partial or complete agenesis of a segment of the uterus associated with infertility, torsion of gravid uterus or inflammation (pyometra and mucometra) (Schulman \& Bolton, 1997; Oh et al., 2005; Vince et al., 2011; Nakamura et al., 2012). Most often the described clinical cases are incidental findings in bitches presented for routine ovariohysterectomy (Schulman \& Bolton, 
1997, Sananmuang et al., 2017) or necropsy (Almeida et al., 2010, Gradela et al., 2013).

It is the first report in the literature of unilateral segmental aplasia of the uterus associated with hypoplasia of the vulva and clinical signs of systemic disease (pyometra) in the bitch.

\section{Case description}

A 6-year-old, nulliparous Miniature Pinscher bitch, weighing $3.8 \mathrm{~kg}$, was presented to the Small Animal Clinic of the Faculty of Veterinary Medicine, Trakia University in Stara Zagora with signs of abdominal pain, excessive vulvar licking, anorexia and lethargy. The owner reported that the last heat was 40 days ago and that no attempts for breeding were made during the previous estrus periods.

On physical examination, there were no changes in the general condition of the animal. Rectal body temperature was 39.0 ${ }^{\circ} \mathrm{C}$, heart rate: $78 \mathrm{~min}^{-1}$, respiratory rate: $39 \mathrm{~min}^{-1}$. The colour of visible mucosal coats was rose-red.

The inspection of the external genitalia showed that the vulva was of very small size, flushed and without any discharge (Fig. 1). The mammary gland was not oedematous and without lactation. Transabdominal ultrasonography (Mindray DC-6 Vet, China, 6.5 MHz convex transducer) revealed unilateral fluid-filled uterine horn just behind the left kidney (Fig. 2). The urinary bladder was found in its normal anatomic location.

To determine complete blood cell counts and biochemical parameters, blood samples $(\sim 2 \mathrm{~mL})$ were collected by venipuncture of the cephalic vein. Complete blood cell counts were assayed on an automated haematological analyser BC2800 Vet (Mindray, China), and blood biochemical parameters - on an automated biochemical analyser BS 120 (Mindray, China). Blood laboratory analysis showed only a marked leukocytosis (Table 1).

The patient was diagnosed with pyometra, so a decision for laparotomy was made. After aseptic preparation of the abdominal region, the bitch was premedicated subcutaneously with $0.04 \mathrm{mg} / \mathrm{kg}$ atropine sulfate (Atropinum sulfuricum; Sopharma; Bulgaria). Fifteen minutes later, anaesthesia was induced by intravenous administration of $0.4 \mathrm{mg} / \mathrm{kg}$ diazepam (Diazepam; Sopharma; Bulgaria) and $10 \mathrm{mg} / \mathrm{kg}$ ketamine (Anaket 10\%; Richter Pharma Ag; Austria). After endotracheal

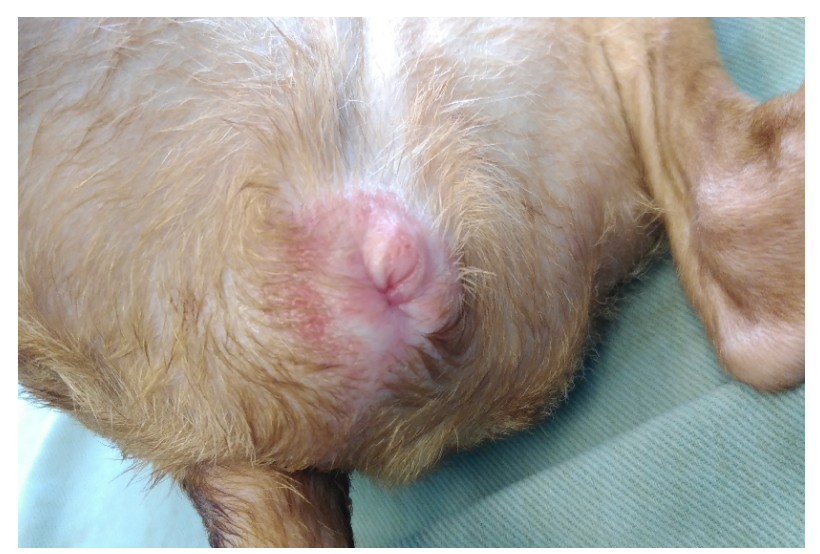

Fig. 1. Vulvar hypoplasia of the patient. 


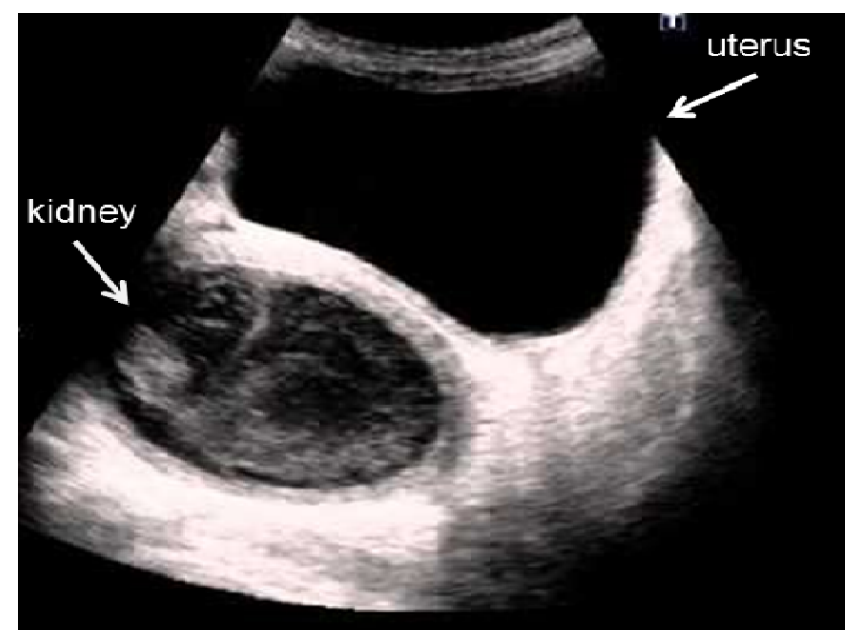

Fig. 2. Ultrasonographic image of the left kidney and fluid-filled uterine horn of the patient.

Table 1. Patient's hematological and blood biochemistry analysis results

\begin{tabular}{lcclcc}
\hline Haematology & Result & $\begin{array}{l}\text { Reference } \\
\text { values* }\end{array}$ & $\begin{array}{l}\text { Blood biochemis- } \\
\text { try }\end{array}$ & Result & $\begin{array}{c}\text { Reference } \\
\text { values* }\end{array}$ \\
\hline $\begin{array}{l}\text { Haemoglobin } \\
(\mathrm{g} / \mathrm{L})\end{array}$ & 155 & $120-180$ & $\begin{array}{l}\text { Alkaline phos- } \\
\text { phatase }(\mathrm{U} / \mathrm{L})\end{array}$ & 127 & $20-156$ \\
$\begin{array}{l}\text { Haematocrit } \\
(\%)\end{array}$ & 39.9 & $37-55$ & $\begin{array}{l}\text { Glucose } \\
(\mathrm{mmol} / \mathrm{L})\end{array}$ & 5.9 & $3.61-6.55$ \\
$\begin{array}{l}\text { Red blood cells } \\
\left(\times 10^{12} / \mathrm{L}\right)\end{array}$ & 6.14 & $5.5-8.5$ & $\begin{array}{l}\text { Aspartate amino- } \\
\text { transferase }(\mathrm{U} / \mathrm{L})\end{array}$ & 49 & $23-66$ \\
$\begin{array}{l}\text { White blood } \\
\text { cells }\left(\times 10^{9} / \mathrm{L}\right)\end{array}$ & 29.5 & $6.0-17.0$ & $\begin{array}{l}\text { Alanine amino- } \\
\text { transferase }(\mathrm{U} / \mathrm{L})\end{array}$ & 28 & $21-102$ \\
$\begin{array}{l}\text { Platelets } \\
\left(\times 10^{9} / \mathrm{L}\right)\end{array}$ & 211 & $200-500$ & $\begin{array}{l}\text { Urea } \\
(\mathrm{mmol} / \mathrm{L})\end{array}$ & 2.7 & $1.67-3.33$ \\
$\begin{array}{l}\text { Mean corpuscu- } \\
\text { lar volume }(\mathrm{fL})\end{array}$ & 64.9 & $60-77$ & $\begin{array}{l}\text { Creatinine } \\
(\mu \mathrm{mol} / \mathrm{L})\end{array}$ & 81 & $44.2-132.6$ \\
\hline
\end{tabular}

${ }^{*}$ Kaneko et al., 2008; Weiss \& Wardrop, 2010.

intubation, the anaesthesia was maintained with isoflurane Terrell $^{\mathrm{TM}}$; Minrad Inc.; USA).

The bitch was placed in a dorsal recumbency and a median laparotomy was performed. The gross examination of the reproductive tract revealed segmental aplasia in the middle of the right uterine horn and enlarged left uterine horn at its tip (Fig. 3). Ovariohysterectomy was performed. The abdominal cavity was closed with cross stitch pattern using USP 2/0 polyglycolic acid absorbable sutures (Marlin; Catgut GmbH; Markneukirchen), and the skin was sutured with simple interrupted non-absorbable sutures USP 2/0 (Vitalon; Dr Hammer \& Co. GmbH; Hamburg). Post operative inspection of the uterus showed no reduction of thickness of the right uterine horn but a total absence of its middle segment (Fig. 4). An incision of the left uterine horn was made 


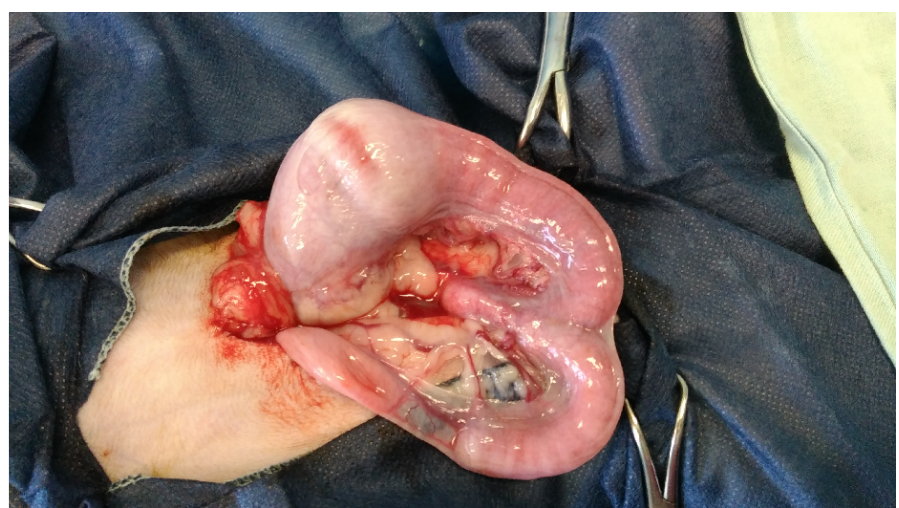

Fig. 3. Intraoperative appearance of the uterus of the patient.

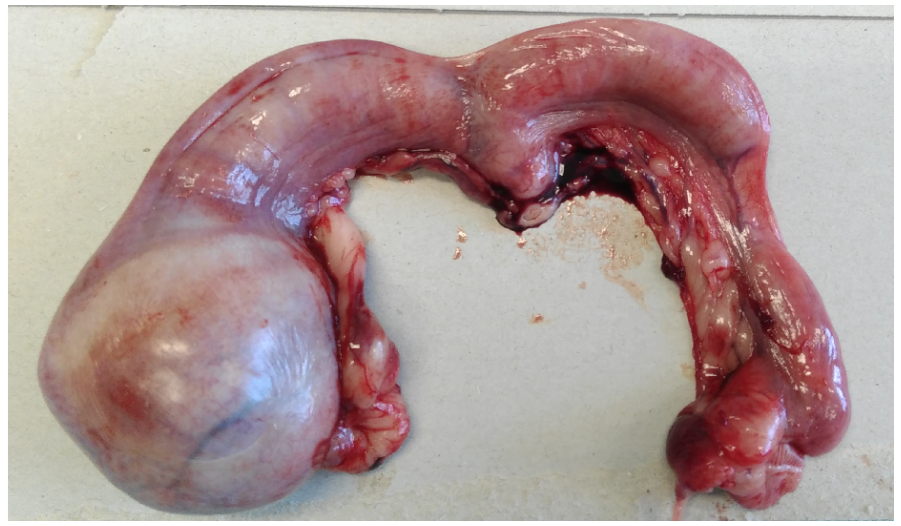

Fig. 4. Internal genitalia of the patient after the ovariohysterectomy.

and its cavity was filled with purulent fluid. Post operative antibiotic treatment with $25 \mathrm{mg} / \mathrm{kg}$ amoxicillin-clavulanic acid (Synulox RTU; Zoetis; USA), orally for 5 days was prescribed. Skin sutures were removed after 10 days. The post operative examination showed that the patient was in a good condition.

The uterine segments in the bitch can show different developmental abnormalities ranging from hypoplasia to complete agenesis (Romagnolli \& Schlafer, 2006, McIntyre et al., 2010). The onset of the clinical signs depends on the location and extension of the agenesic segment (Colaço et al., 2011) and the main outcome is ac- cumulation of a sterile fluid with distension of uterine walls because of the obstruction to the normal outflow of endometrial gland secretions (McEntee, 1990; Romagnolli \& Schlafer, 2006; McIntyre et $a l ., 2010)$. Due to the excessive pressure, the patient may present mild signs of uterine disease (abdominal distension, tenesmus or dysuria) and usually haematological and blood biochemistry results are within or close to normal values, but the uterine segment retaining patency is possible to develop a pyometra, which may completely change the clinical findings of the patient (Colaço et al., 2011). 
The severity of the defect influences the reproductive outcome and the presence of clinical side effects, which are most often increased dimensions of the uterus and signs of mucometra or pyometra (Colaço et al., 2011). In our case the patient also showed specific complication to the uterine abnormality (pyometra), but the most interesting and unique fact was that the inflammation comprised only the tip of the opposite uterine horn. The areas cranial to the non-developed part of the uterine horn and the other parts of the uterus were normal.

In the bitch, the external genitalia, the vulva, the vestibule of the vagina, the urethra, and the urinary bladder are all derived from the embryonic urogenital sinus. It forms the paramesonephric tubercle, which is canalised and fuses to the genital folds to form the vestibule; the genital swellings form the vulvar lips (Johnston et al., 2001). Vulvar hypoplasia (immature vulva) is a very rare type of congenital abnormality during the embryonic development which arises from imperfect joining of the genital folds to the genital swellings that narrows the vulvar opening (Wykes \& Soderberg, 1983). The clinical signs consist of inability to breed naturally (Johnston et al., 2001).

Congenital abnormalities of the uterine horns are often associated with unilateral renal agenesis because of their common embryonic origin (Senger, 1995), but aplasia of the associated ovary is very rare due to its different embryologic development from the gonadal ridge (McEntee, 1990). In our patient no other congenital abnormalities of the internal genital organs or kidneys were observed, but it was found that the vulva was hypoplastic. This is the first described report of unilateral segmental uterine aplasia with vulvar hypoplasia at the same time.

\section{REFERENCES}

Almeida, M., E. Rezende, A. Lamounier, M. Rachid, E. Nascimento, R. Santos \& G. Valle, 2010. Aplasia segmentar de corpo uterino em cadela sem raca definida: relato de caso. Arquivo Brasileiro de Medicina Veterinária e Zootecnia, 62, 794-800.

Colaço, B., M. Pires \& R. Payan-Carreira, 2011. Congenital aplasia of the uterinevaginal segment in dogs. In: A Bird's Eye View of Veterinary Medicine, pp. 165177.

Gradela, A., A. Macedo, M. Matos, R. Lima \& V. Franzo, 2013. Rare birth defects associated with Morgagni hernia and segmental aplasia of uterine horn in bitch: Case report. Ciencias Agrarias, 4, 1841-1850.

Johnston S., M. Kustritz \& P. Olson, 2001. Canine and Feline Theriogenology. WB Saunders Company, London, United Kingdom.

Kaneko, J., J. Harvey \& M. Bruss, 2008. Clinical Biochemistry of Domestic Animals, $6^{\text {th }}$ edn, WB Saunders, Philadelphia.

Kennedy, P. \& R. Miller, 1993. The female genital system. In: Jubb, Kennedy \& Palmer's Pathology of Domestic Animals, vol. $3,4^{\text {th }}$ edn, Academic Press, San Diego, pp. 349-469.

McEntee, K., 1990. Reproductive Pathology of Domestic Mammals, $1^{\text {st }}$ ed. Academic Press, San Diego, CA.

McIntyre, R., J. Levy, J. Roberts \& R. Reep, 2010. Developmental uterine abnormalities in cats and dogs undergoing elective ovariohysterectomy. Journal of the American Veterinary Medicine Association, 237, 542-546.

Nakamura, K., M. Yamasaki, T. Osaki, H. Ohta, N. Sasaki, K. Aoshima, T. Kimura \& M. Takiguchi, 2012. Bilateral segmental aplasia with unilateral uterine horn torsion in a Pomeranian bitch. Journal of the American Animal Hospital Association, 48, 327-330.

Oh, K., C. Son, B. Kim, S. Hwang, Y. Kim, S. Park, J. Jeong, C. Jeong, S. Park \& K. 
Cho, 2005. Segmental aplasia of uterine body in an adult mixed breed dog. Journal of Veterinary Diagnostic Investigation, 17, 490-492.

Roberts, S., 1971. Veterinary Obstetrics and Genital Diseases. Woodstock, VT: Self published, $1^{\text {st }}$ edn.

Romagnoli, S. \& D. Schlafer, 2006. Disorders of sexual differentiation in puppies and kittens: a diagnostic and clinical approach. Veterinary Clinics of North America Small Animal Practice, 36, 573-606.

Sananmuang, T., P. Jeeratanyasakul \& K Mankong, 2017. Segmental aplasia of uterine horn in bitch: Case report. The Thai Journal of Veterinary Medicine Supplement, 47, 197-198.

Schulman, M. \& L. Bolton, 1997. Uterine horn aplasia with complications in two mixed-breed bitches. Journal of the South African Veterinary Association, 68, 150153.

Senger, P., 1995. Embryogenesis of the pituitary gland and male or female reproductive system. In: Pathways to Pregnancy and Parturition, $2^{\text {nd }}$ ed. Current Conceptions, Ephrata, pp. 80-87.
Vince, S., B. Zevrnja, A. Beck, A. Folnozic, D. Geres, M. Samardzija, J. Grizelj \& T. Dobranic, 2011. Unilateral segmental aplasia of the uterine horn in a gravid bitch-a case report. Veterinarski Arhiv, 81, 691-698.

Weiss, D. \& K. Wardrop, 2010. Schalm's Veterinary Hematology, $6^{\text {th }}$ edn, Blackwell Publishing, Iowa..

Wykes, P. \& S. Soderberg, 1983. Congenital abnormalities of the canine vagina and vulva. Journal of the American Animal Hospital Association, 19, 995-1000.

Paper received 25.10.2018; accepted for publication 18.01.2019

\section{Correspondence:}

Anton Antonov

Department of Obstetrics, Reproduction and Reproductive Disorders,

Faculty of Veterinary Medicine,

Trakia University,

Stara Zagora, 6000, Bulgaria

e-mail: anton.antonov@abv.bg 